\title{
Sciendo
}

DOI: $10.2478 /$ jolace-2019-0001

\section{Intercultural competence of university teachers: a challenge of internationalization}

\author{
Anna Zelenková \& Dana Hanesová \\ Matej Bel University in Banská Bystrica, Slovakia \\ dana.hanesova@umb.sk; anna.zelenkova@umb.sk
}

\begin{abstract}
The aim of the authors is to respond to the growing demands on the intercultural competence of university teachers due to intensified internationalization pressures on higher education, especially due to the growing number of students and teachers' international exchanges. They report on an intercultural course design responding to this need, presenting a case study from Slovakia. First, they define the need of intercultural competence of university teachers, especially those teaching in English-medium study programmes. Then they share a) findings from a needs analysis preceding the design of a new curriculum for an intercultural competence course (ICC) at Matej Bel University (MBU) with three aims (development of linguistic, cultural and pedagogic competences); and b) results from action research during piloting the ICC course. A comparison of 2011 and 2018 surveys pointed to the growing dominance of the English language, including an increasing command of English by MBU teachers. The ICC curriculum, tailored to the pre-identified teachers' needs, proved to be a feasible way of facilitating their intercultural competence. Its implementation revealed persistent prejudices and difficulties associated with overcoming them. It also confirmed a significant deficit in preparing university teachers for their role as intercultural mediators in English-medium courses.
\end{abstract}

Key words: intercultural competence, teacher training, higher education, internationalization, English-medium studies

\section{Introduction}

Now more than ever before, university students, teachers, researchers, and other staff are exchanging their place of work or study to gain international experience and share their expertise in teaching/learning processes, educational management, publishing, and research collaboration. Teaching in an international university context has become a challenge for all university teachers, as they should acquire new concepts and paradigms in order to manage diversity in education (Gopal, 2011).

As the rising level of internationalization of universities is evident-especially in an influx of international students - there is a growing need for the university teachers to be able to communicate with them in order to ensure effectiveness in 
educational processes. Universities with their foreign students and teachers, representing different cultures, have become platforms of intercultural communication (cf. Janík, 2017). This communication will turn out to be beneficial only if it is both linguistically and culturally appropriate-open to otherness, flexible in changing routines, eager to investigate and appreciate different cultural values, practices, or norms, evaluating them without prejudices and stereotypes.

Raising intercultural competence at universities might also enhance the chances for employability of their graduates in the international labour market. Although Europe as a continent has always been a multilingual and multicultural region, the current EU educational policy requires an equal opportunity and challenge for all its inhabitants to be educated for communicating and working in the internationalized professional environment. Therefore, university teachers should support cultural diversity by self-reflection, learning, teaching and training intercultural strategies that respond to all students' needs, expectations, experiences, and cultural background; by revealing social stereotypes, and developing their own cross-cultural teaching strategies ('A New Skills Agenda for Europe', 2016; 'European Skills/Competences, Qualifications and Occupation' by ESCO, 2018).

University teachers are expected to be both internationally acknowledged scientists and, at the same time, effective practitioners in linguistically, culturally and racially diverse classrooms and schools (Banks, 2010). Arguments for extending the capability of university teachers for intercultural dialogue are based on the assumption that mutual understanding among various cultural groups is beneficial, even as their members become more aware of differences (Javorčíková, 2009). Intercultural competence of university teachers is essential for reducing the barriers between them and their students representing various cultures (The European Centre for Clinical Research Training, 2018). Are they prepared for this new task? We are trying to answer this question in our article.

\section{The intercultural competence of university teachers}

An interculturally competent person can be described as a person not only with some acquired knowledge on culture and its cognitive comprehension, but competent to demonstrate intercultural empathy, respect, tolerance, sensitivity and flexibility, as well as the openness to negotiate, the ability to argue, the good will to understand others, discuss with them, and reach consensus (Sun, 2014). $\mathrm{He} / \mathrm{she}$ is a person interculturally aware, sensitive and adroit (Chen \& Starosta, 1996). The interculturality should penetrate into all three dimension of his / her personality and relationships: cognitive (awareness of cultures and selfawareness), affective (tolerance, empathy, appreciation of diversity) and behavioural (acting towards 'others', interaction and cooperation skills) (Zelenková, 2010; Barrett, Byram, Lázár, Mompoint, Gaillard, \& Philippou, 2014; 
Genç, 2018).

According to Deardorff's pyramidal model of intercultural competence, the prior emphasis should be placed on attitudes (respect, openness, and curiosity and discovery) that represent the basic required level of intercultural competence (Deardorff, 2006, p. 254). In the case of university teachers, appropriate, unprejudiced attitudes include openness toward learning from professionals and students representing other cultures and active attempting to build cooperative relationships with them. If teachers' personal attitudes are accompanied by their knowledge about cultures, and critical thinking skills, then the desired internal (adaptability, flexibility, empathy, etc.) as well as external outcomes (proper and effective communication and behaviour) may appear (Deardorff, 2006). The intercultural competence of a teacher presupposes the shift from the attitudinal level to the level of intercultural behaviour and interaction in various cultural professional contexts. University teachers teaching various scientific courses to culturally mixed groups of students have to become facilitators of such a comprehensive kind of intercultural teaching and learning (Crose, 2011).

In case of using English-the current lingua franca in international communication-a new cultural role of English, is advocated, for example, by Morgado (2017) or earlier in the Council of Europe (CoE) document 'Autobiography of Intercultural Encounters' by Byram, Barrett, Ipgrave, Jackson, \& Méndez García (2009).

Interculturally competent university professionals should be aware of culturally different ways of viewing the world, as evidenced in the thinking, habits, and behaviours of their foreign colleagues and students (Anossova \& Dmitrichenkowa, 2018, p. 73). They can initiate positive, sensitive and effective communication-verbal and non-verbal-with students coming from various cultures (Byram et al, 2009; ESCO, 2018). Opportunities for harmonious interaction and successful collegial dialogue that lead to mutual comprehension without disrupting an individual's integrity are growing in proportion to the level of professionals' intercultural competence. The university teachers' role is to mediate-harmonize the relationship in the multicultural group of students and colleagues. That implies that the task of university teachers is not only to function in a role of a science-related content expert-ideally with a high command of the foreign language, and teaching a course in it. They are to master a skill of teaching students from various cultures in such a way, which can become a means of their potential reconciliation.

The research indicates the weak preparedness of some investigated universities for this new societal situation. Little attention has been paid to the role and quality of English used in the English-medium programmes or in academic research (Chigisheva, Soltovets, \& Bondarenko, 2017, p. 145), to the relevant preparation of teachers to teach in these programmes (Dearden, 2014), or, 
generally, to the development of teachers' intercultural knowledge and skills for 21st century schools (Lázár, 2011, p. 113-126). Zerzová's research (2018, p. 106) shows the persistent emphasis on the cognitive dimension of teachers' competence development, in line with the "traditional teaching culture".

If nurturing intercultural competence of university teachers is to be successful, it should focus not only on transmission of the knowledge of some superficial information about cultural differences, but especially on formation of their attitudes, and on experiential and constructive acquisition of the values of tolerance and justice (Kosová, 2012). The transformation of teachers and students' identity via nurturing their intercultural competence is a "dynamic performative process conditioned by social norms typical for the culture of schooling that they are embedded in and that are imposed by the school curriculum in its largest sense" (Lujić, 2018, p. 76). This raises a need to design a more interculturally aware curriculum, which uses the culture of students involved in the educational process as their learning resource (Arphattananon, 2018) and where the process of teaching and learning culture happens as "a relational process" (Michelson, 2017). In such way, the university teachers may actively mediate not only the semantic models of interculturalism but also their axiological dimensions (Vančíková, 2013).

\section{Research of raising intercultural competence of teachers in a Slovak university}

The growing presence of foreign students at universities raises a number of important questions, often not explicitly treated in the university strategies on internationalization. To which extent are the university teachers without any prior intercultural training able to respond to the multiple needs of their foreign students? For example, are they able to respond to their growing need for academic language skills (to read and write academic texts in a foreign language, to research for suitable materials, to comprehend university lectures, to make notes from them, to complete ongoing and final assignments)? Or to their need for support when facing the situation of a culturally different, unknown university environment, including exams, and classroom interaction? Are the teachers of the English-medium study programmes to multicultural groups of students able to interact with them in a pedagogically and interculturally competent way?

Although most universities in the Central European post-communist region respond to the challenge of internationalization by producing their strategic policy documents on internationalization, practice at most Slovak universities shows signs of insufficient implementation of such declarations. There are visible deficiencies in the pedagogical and didactic preparedness of university teachers for teaching in an international class. Generally, there are no standards of the level of their intercultural competence (ICC). Their ICC training usually happens ad hoc, 
via international cooperation in various projects which might focus, for example, on wider competence for global citizenship (Svitačová et al, 2015). However, a professionally supervised discussion on the intercultural aspects of the interaction with foreign students is often missing.

The repeated feedback from several students studying at Matej Bel University (MBU) in Banská Bystrica as well as from the personal experience of foreign language MBU teachers or incoming foreign teachers has indicated an urgent need to improve ICC of the MBU teaching staff. In light of this feedback, the question arose: How can university teachers be helped to grow in their intercultural competence? In 2011, a group of foreign language teachers from the Faculty of Economics decided to prepare an ICC course curriculum for the MBU teachers planning to teach or involved in teaching in English-medium programmes (via a project 'Enhancing Foreign Language-Medium Programmes at MBU' No. 26110230025, co-financed from the European Social Fund). First, they carried out a survey of linguistic and intercultural needs of MBU teachers. Based on the analysis of actual linguistic and intercultural needs, they designed and piloted the first version of the ICC course in the years 2012-2014. Due to the low number of teachers of French and German, only one course for teachers of German was designed. The following research report focuses solely on the course in English.

The proposed ICC course had three kinds of improvements as its triple aim: a) general communicative competence in English (as a pre-requisite for teaching in English-medium programmes); b) pedagogical-didactic competence (pedagogic communication and teaching-learning skills); and c) the intercultural competence (intercultural awareness, knowledge, and communication skills) of MBU teachers.

The ICC curriculum focused on various topics related to the issues which the teachers were dealing with in their English-medium courses (teaching and learning strategies, development and assessment of critical thinking skills, differences between the learner-centred and teacher-centred approach, team teaching principles, identification of learning outcomes, questioning and discussion techniques, or the concept of diversity in international groups of students such as education background, education culture, multiple intelligences, requirements on student's performance).

As for the methodological procedure, a pedagogic case study was used. It consisted of a series of pedagogic situations (events), which required analysis, identification of problems and suggestion of possible solutions. The training method was based on Kolb's experiential learning cycle. Situations were simulated and video series were used to allow teachers to experience 'otherness' in the broadest terms (relation to authority, body language, work relations, nonjudgmental communication); to reflect on the experience and make generalizations backed by theories; and, finally, to apply knowledge they gained in their own teaching practice. Besides contact lessons, a part of the ICC course was 
accomplished via the individual study using an electronic online learning environment with pre-prepared learning activities aimed at individual improvement, such as listening and reading comprehension exercises, or language use and grammar exercises.

\subsection{Research methodology and research participants}

Quantitative survey of needs analysis: The first round of the needs survey was completed in 2011, in conjunction with the operation of joint-study programmes between MBU and French and German universities. The second survey of teachers' needs was conducted in 2018 in order to analyse the teachers' current needs, to investigate the differences between the two sets of data in order to update the course in the future. The idea of measuring the international needs of MBU teachers has become also the theme of the newly constructed research project proposal with a wider national impact (KEGA 004UMB-4/2019).

The questionnaire consisted of nine multiple-choice questions. All MBU teachers got a chance to choose one or more alternatives based on their selfassessment of their own linguistic and intercultural skills. The final number of respondents in 2011 was 185 teachers, the second set in 2018 consisted of 218 teachers ( $41 \%$ of all MBU teaching staff), representing all MBU faculties. Although the focus of this study is the intercultural competence of university teachers, the survey authors did not consider it wise to separate it out from the rest of the linguistic competences (cf. CEFR, 2018).

Qualitative action research of the ICC course: In parallel with the ICC course piloted teaching, its authors carried out thorough action research both to increase accountability in relation to the above-mentioned granting scheme and to improve the course so that it yielded more benefits to both the institution and the students enrolled. The piloted ICC course was attended by twenty MBU teachers teaching / planning to teach in English-medium courses.

The action research of the ICC course used several evaluating techniques, predominantly observation, field notes, interviews, reflections, analysis of written assignments, and other kinds of feedback allowing the evaluation and, later on, innovation of the first draft of the ICC course curricula.

\subsection{Findings}

The comparison of both surveys (in 2011 and in 2018) among MBU teachers showed that, based on self-assessment, the number of MBU teachers (2018) with an advanced level of English doubled (from 12.6\% to 24.8\%) and the number of pre-intermediate users of English fell from 41\% to 28.4\% (see Graph 1).

Graph 1: The university teachers' level of command of English (in 2011 and in 2018) 


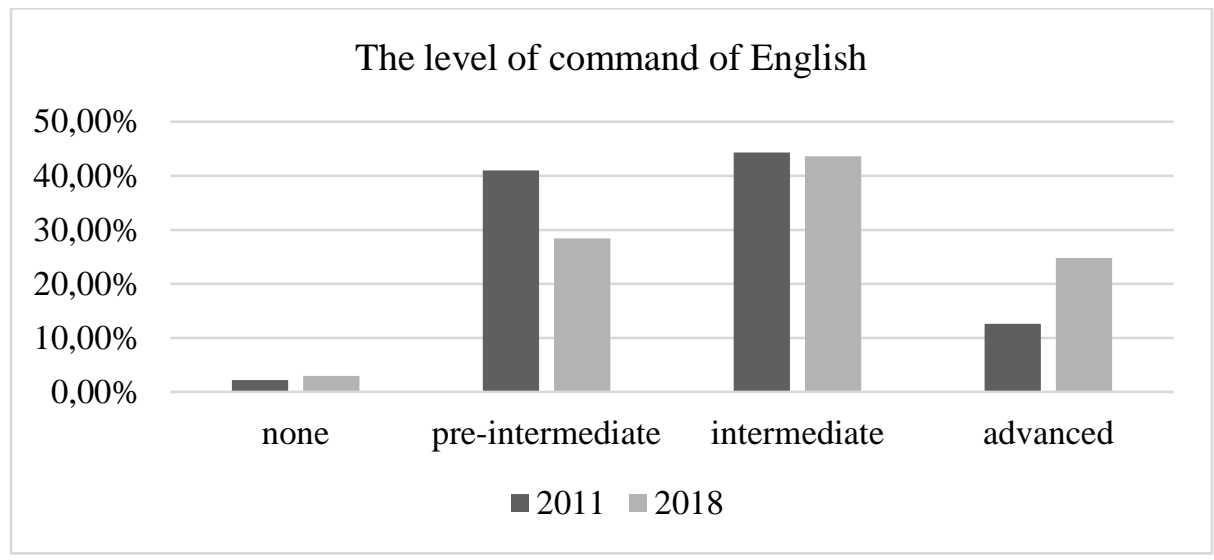

On the other hand, the level of command of three other world languages, often used in the past, was lower. The number of intermediate and advanced users of French fell from $8.7 \%$ to 4 or $5 \%$. The number of users of German on the intermediate level fell from $21 \%$ to $12 \%$ and on advanced level from $9.8 \%$ to $6 \%$. The number of users of Russian fell from $29 \%$ to $12.1 \%$ in the intermediate group and from $6.9 \%$ to $5.5 \%$ in the advanced group. In all these languages, the number of those respondents without any command of these foreign languages rose (in French, from $60.9 \%$ to $79 \%$, in German, from $14.7 \%$ almost threefold to $39.7 \%$ ).

Graph 2: The university teachers' level of command of German (in 2011 and in 2018)

\section{The level of command in German}

$60,00 \%$
$40,00 \%$
$20,00 \%$
$0,00 \%$
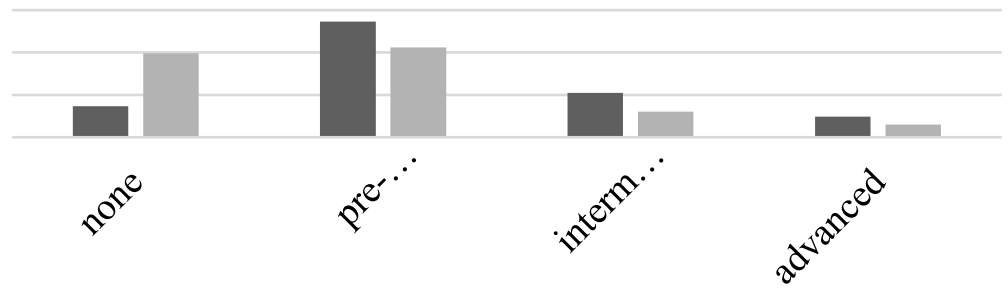

ロ $2011 \square 2018$

Graph 2 presents an example of these shifts. There was only a very slight increase in the numbers of pre-intermediate and advanced users of other relatively rare foreign languages (by 1-2\% in Spanish, Italian, Chinese, Arabic, and Latin). 
Also, the numbers of teachers teaching or wanting to teach English-medium courses fell by $3.9 \%$ from $59.5 \%$ in 2011 to $55.6 \%$ in 2018 . Those teachers who teach or would like to teach in a foreign language could chose in which language they would like to do it (Graph 3). Their responses were in line with their growing competence in English and declining competence in other foreign languages. In 2011 over $70 \%$ and in 2018 almost $86 \%$ of such respondents could imagine teaching English-medium courses. The number of instructors teaching (or planning to teach) in German dropped fourfold-from $15.8 \%$ to only $4 \%$, French from $7.9 \%$ to $5.8 \%$ and Spanish from 1.9 to zero. Only the motivation to teach in Russian remained at the previous level.

Graph 3: The willingness to teach a course in a foreign language (in 2011 and in 2018)

Foreign language in which I teach/plan/would like to teach my course

$100,00 \%$
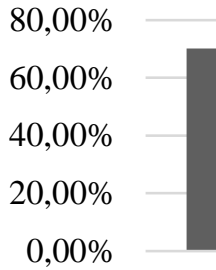

English

French

German

Russian

Spanish

Other

- $2011 \square 2018$

The question about the perceived level of difficulty associated with teaching English-medium courses revealed other interesting data. The 2018 respondents with a higher command of English considered all components of teaching an English-medium course less difficult than the 2011 respondents (see Table 1).

Table 1: Opinions about difficult components in teaching an English-medium course 


\begin{tabular}{|c|c|c|}
\hline Difficult/very difficult components in teaching & 2011 & 2018 \\
\hline an English-medium course - opinions & & \\
\hline $\begin{array}{l}\text { Contributing to and leading a discussion, } \\
\text { argumentation }\end{array}$ & $68 \%$ & $61 \%$ \\
\hline $\begin{array}{l}\text { Language of professional text (grammar, } \\
\text { logical structure, subject related, academic } \\
\text { discourse) }\end{array}$ & $65.4 \%$ & $65.4 \%$ \\
\hline $\begin{array}{l}\text { Explanation of the subject's professional } \\
\text { content }\end{array}$ & $64.5 \%$ & $58 \%$ \\
\hline Oral testing & $60 \%$ & $50 \%$ \\
\hline $\begin{array}{l}\text { Communication with student in class and out } \\
\text { of class (mentoring, consultations) }\end{array}$ & $50 \%$ & $47 \%$ \\
\hline $\begin{array}{l}\text { Assessment and evaluation of written } \\
\text { assignments (commenting on results, justifying } \\
\text { decisions, explaining the level of achievement) }\end{array}$ & $50 \%$ & $40 \%$ \\
\hline
\end{tabular}

Complementary evidence that all elements of teaching an English-medium course are easier for advanced language users (2018) is presented in Graph 4, with the highest percentage of respondents considering teaching a particular component to be easy or easiest in teaching English-medium courses.

Graph 4: The easiest components in teaching an English-medium course (in 2011 and in 2018)

The easiest components in teaching an English-medium course

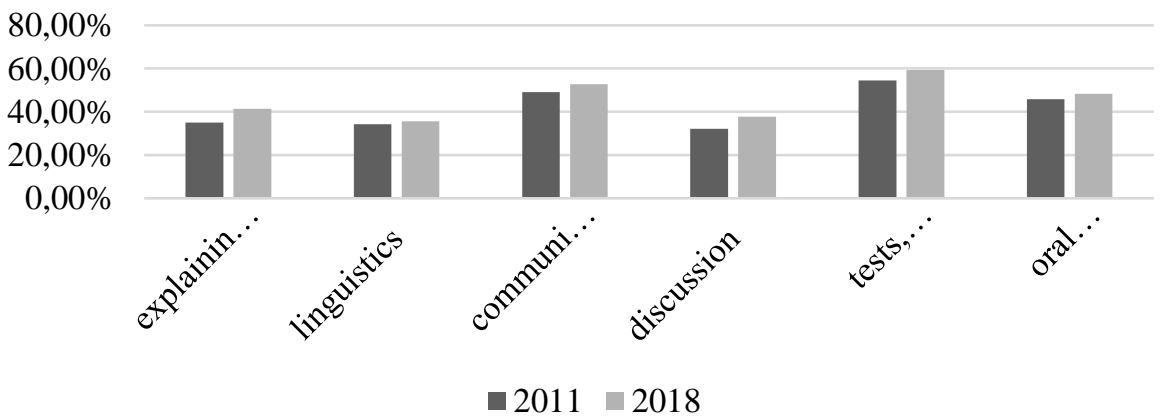

Participants also responded to the question which language skills they would need to improve (Graph 5). The biggest group of respondents in 2011 and in 2018 
indicated the most needed area to be general proficiency in English-up to 70\%. Next, they indicated the improvement of conversation skills-55\% in the 2011 group, $61 \%$ in 2018.

Graph 5: The desire to improve a certain skill in order to teach in English (in 2011 and in 2018)

I would need to improve the following skills in order to teach in English

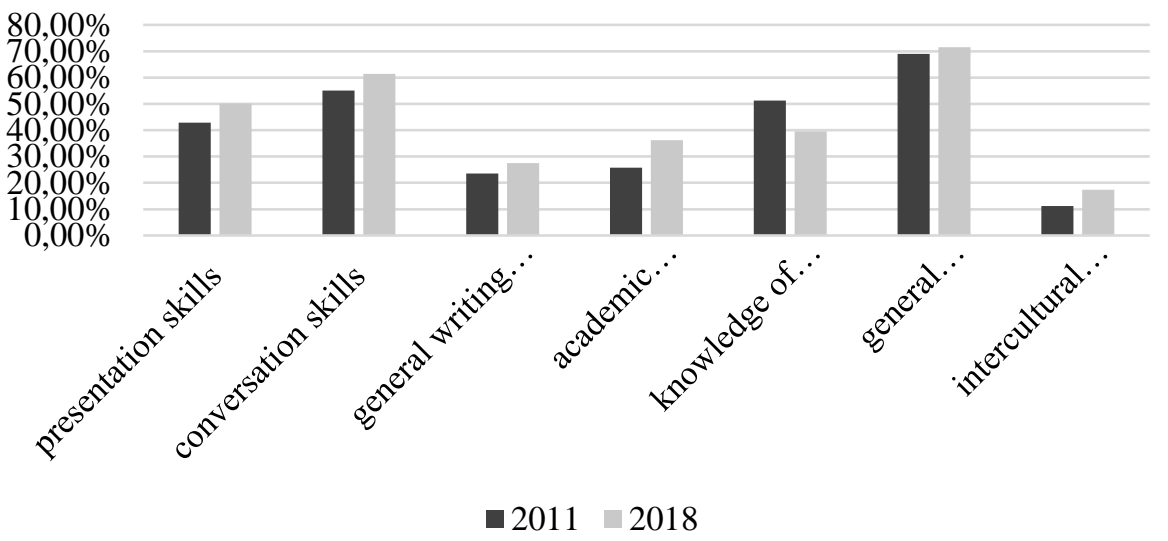

The 2018 respondents considered it most important to improve their oral communication skills (e.g. presentation skills). Their desire to improve in academic and professional language proficiency fell in 2018. They did not feel such strong a need to focus on science-related terminology (from 51\% to 40\%). On the other hand, when it comes to writing, they put more emphasis on their academic writing than on their general writing skills (from 25\% in 2011 to $36 \%$ in 2018). The need for improvement was raised also in the area of intercultural awareness. About 12\% of respondents in 2011 and almost 18\% in 2018 indicated that multicultural education was an area needing their attention.

The administrators of the questionnaire in 2018 added one more question for the respondents about the environment in which they would like to develop their linguistic and intercultural competence. Over $60 \%$ of teachers welcomed the opportunity to improve it at MBU as their workplace, most of them in the English language (80\%).

\section{Findings from action research}


Observations, interviews and ongoing assessment of the ICC course confirmed the presence of the combined effort of the ICC course authors, its teachers as well as participants towards the fulfilment of all three constitutive objectives of the ICC course. As a thread, through all three objectives the cultural element was visible, playing an integral part in the ICC course.

The case study method allowed for dealing with more than one pedagogic issue at the same time and thus provided opportunities for active participation and discussion. Participants were solving the problems individually and in groups. The course gave the participating teachers an opportunity to clarify and reflect their own philosophy and approaches to teaching.

The final feedback from the course participants revealed that most of them welcomed the opportunity to improve not only their intercultural but also their pedagogical competence, namely the knowledge and application of pedagogical theories necessary for proper decision-making in educational practice. The use of the method of a case study helped them to acquire skills of using various organizational forms, such as pair and group work, defining learning outcomes, questioning and discussion strategies, and assessment skills. Although the final presentations of the participants revealed that most of them welcomed the new methodology of the ICC course, and were willing to implement the innovative methods into their English-medium course, others demonstrated their resistance against innovative methods and forms of teaching, especially to group and peer work. Their deficit of theoretical knowledge backing their teaching methods was evident.

The action research detected very low awareness about other educational cultures by up to $70 \%$ of the ICC course participants. Teachers still carry with them lots of deep-rooted stereotypes about nationalities and ethnic groups. They make generalizations in the assessment of students' performance based on nationality. For example, some teachers put foreign students into stereotypic national or ethnic groups, such as: students from this country are lazy or they do not know how to make presentations, students from another country are always good in speaking, and you can rely on them to contribute to class discussion, etc.

On the other hand, it was evident that during the course the participants' attitudes, expressions and responses gradually changed towards greater openness and understanding of cultural diversity in their international university setting. This shift was nurtured by activities specifically prepared by the curriculum designers. For example, the course attendants had to face the fact that international groups of students would bring with them different values, beliefs and norms of behaviour, creating a completely new situation. They acquired a new view of perception of their own culture and realized stereotypes in their thinking, communication and behaviour. 


\subsection{Discussion and implications from needs analysis}

In accordance with the global trends, the survey results confirmed the dominant position of English as a lingua franca in MBU courses for international students, and therefore the necessity to conduct the ICC courses for university teachers in the first place in English. The increased level of mastering English reflects the intense internationalization of education and the societal attention paid to the effective foreign language pedagogy, including the current education policy in Slovakia, offering English as the first foreign language at all levels of education (from elementary to postgraduate).

The survey results also indicate the importance of a tailor-made ICC course curriculum fitting the identified needs of its participants. The ICC course should focus on such components in teaching English-medium courses that the attendants mark as the most difficult. In our case, the group of identified needs involved the necessity to lead discussions and argumentation, to engage effectively in academic discourse and difficult professional texts, to explain professional content and vocabulary, and to conduct oral tests. Although the respondents labelled general communication with students and assessment of their written assignments to be the easiest components, it is important to remember that more than half of them still expressed their need to improve in these skills. When it comes to writing, the teachers put more emphasis on their academic writing than on their general writing skills (from 25\% in 2011 to $36 \%$ in 2018). This finding may reflect the current growing pressure on publishing in English, and the university teachers' stronger awareness of their deficiencies in academic writing (Cole \& Spišiaková, 2017).

The reduced number of $\mathrm{MBU}$ teachers teaching or willing to teach in foreign languages might be the result of ending externally subsidized projects at MBU. Another reason might be the fact that the enthusiastic MBU teachers previously involved in teaching courses in a foreign language actually did not receive any adequate support-either methodological or financial-to continue to develop the international spirit of the university by their activity. Of course, further research would be required to confirm these causes. The good news on that front is that in some cases negotiations are underway to continue joint-study programmes or design new ones.

A good sign of the gradually opening community of university teachers toward growing interculturalism is that their intercultural awareness has increased since 2011.

The fact that a majority of MBU teachers welcomed the opportunity to improve their linguistic, pedagogic and intercultural competence at their workplace leads us to expect that the next application of the ICC course in the university setting has the potential to be useful for the university teachers. 


\subsection{Discussion and implications from action research}

The interviews with the attendants of the ICC course confirmed their personally perceived need to develop their general communicative competence in English. Under the pressure of internationalization, university teachers realize the challenge to enhance their ability to communicate with their students in a foreign language, and to do so in a culturally and pedagogically competent way. For example, they have to be able to clearly set and explain learning objectives, to explain and justify their assessments in relation to the number of credits offered, and to assist students in their learning (for example, giving advice related to the available resources, such as libraries or online databases, providing help through consultations and mentoring, and socializing with students during various events such as the International Students Day).

The ICC course has facilitated development not only of linguistic skills but also of pedagogical skills of its attendants. The feedbacks indicated that the learnercentred approach with the teacher being a facilitator and acting as one of several resources was successfully applied in the ICC course. It has become evident that the ICC course should lead the teachers to believe that "nobody should be disadvantaged ... all students require some level of support in acquiring academic cultural capital and adjusting to higher education practices ... it should include all students' backgrounds and cultures" (Caruana, 2011, p. 3). The ICC course should offer freedom for significant choice among teaching methods enhancing critical thinking skills including heuristic and problem-solving methods, discussion, or reflection.

Through the feedback and qualitative evaluation, the ICC course has proved to be feasible in contributing to the raised level of intercultural competence of most ICC course participants related to their comprehension of the concept of culture and their awareness of multicultural values. They were able to see the emphasis on the need of re-shaping their sets of reactions to various cultural issues, as well as openness to valuing other cultures.

On the other hand, teacher trainers in the piloted course observed that in spite of these perceptions, the communication with the participants during the ICC course showed some discrepancies between their real competences in interpersonal communication and those that they perceived and verbalized. Skills at communicating with students in the classroom or in classroom management serve as examples. It turned out that culturally responsive teaching might remain to be one of the subtlest deficits of an ICC course for most ICC participants. Although they were 'culturally emphatic', most course participants did not perceive their intercultural awareness as critical (comparable to results of Genç, 2018). One of the teachers mentioned the case when an Erasmus student from Finland claimed that before coming on Erasmus to Slovakia, she had never written a certain kind of test used by the Slovak teacher and that such a difference of 
educational culture might have led to her weaker exam results. In another example, a group of students from another culture got poor final assessment simply because a Slovak teacher assessed their presentations in class as inadequate (not knowing that those students were never required to do presentations in their home university as part of their final assessment).

The most painful part of the ICC courses was emerging evidence that some participants made strict assessments based on 'otherness' as something differing from 'our' (Slovakian) norms (which were considered to be the only right values). The course revealed several teachers' unconscious prejudices.

Nevertheless, the observations and interviews in this action research indicated that the ICC course facilitated to raise MBU teachers' awareness of stereotypes in their thinking, behaviour and ability to view other people's behaviour from the perspective of those people's own cultural backgrounds. It was the first time the MBU teachers in foreign language courses got such a professionally supported opportunity to recognize their own intercultural attitudes and stereotypes and to improve in related intercultural skills. Their final interviews indicated that they appreciated the opportunity to gain such self-awareness.

Due to our action research, we can suggest a list of necessities to facilitate university teachers' competences to work effectively in an international education context (Stone, 2006). Levels of communicative and social skills that enable them to establish positive relationships and enhance positive social interaction at their workplace should be encouraged. Supportive learning environments for the development of their understanding of cultural diversity and the growth of their 'global citizenship' competence should be well structured and designed.

\section{Conclusion}

In our study, we pointed at the current trend of internationalization of universities, manifested in the increasing frequency of intercultural exchanges and the mobility of both students and teachers. Universities have become international workplaces and the professionals who work there must face these new challenges. Based on the experience and practice of universities in the Central European region, we warned that university teachers have not been systematically trained and prepared for the new requirements related to this kind of professional intercultural communication.

Our experience with facilitating the development of university teachers' professional communication and intercultural skills confirmed the existence of an enormous deficit of attention paid to this issue. The fact that university teachers facing the teaching of growing numbers of international students are not offered adequate professional training is often simply ignored and the examples of good practice are rather rare (Lázár, 2011). The most important conclusion we want to 
emphasize is the pressing need for raised awareness about this deficit at the international, national (governmental), and institutional (managerial) level.

Our desire was to present a modest proposal for tackling this deficit via offering a specialized intercultural communication training for university teachers. Its tailor-made content should reflect their subject-specific communication needs, keeping in mind that they have to be prepared to operate in an increasingly international environment. Thus, the vision of university teachers' lifelong education has to be elaborated on a more systematic level, just as teachers at elementary and secondary schools are continually educated. However, an important question remains. Who should be responsible for promoting the systematic preparation of university teachers for the challenges of the international environment? We realize that the creation of such teacher preparation requires an interdisciplinary endeavour as it involves raising teachers' pedagogical expertise, communication competences and interculturality. In the case of MBU, several foreign language teachers with intercultural learning experience and aware of this need, have initially prepared and conducted such training but they do not consider this a system solution. A body of experts or an intercultural training institution will be required.

The action research during the implementation of the ICC course curriculum uncovered the discrepancies between the expectations of the course teachers and the attendants' personal perceptions and the actual state of their underdeveloped intercultural attitudes. These findings remind us of the above-quoted appeals from Deardorff (2006) and Byram et al (2009) for the cultivation of the university teachers' prejudicial attitudes and stereotypical thinking. Overcoming them will require targeted training efforts in the near future. It is obvious that university teachers participating in English-medium courses, in addition to being able to teach the lingua franca, can affect a wide range of students. The main reason of their intercultural training is to raise their awareness of their individual responsibility for becoming ambassadors among cultures, for understanding cultural diversity, for being interculturally competent communicators, mediators among professionals and students from various cultural backgrounds, supporting and disseminating the idea of global citizenship.

\section{Acknowledgment}

This paper is one of the outputs of the research project KEGA No. 033UMB4/2017 (E)migration as a political, ethical, linguistic and cultural phenomenon in the era of globalization and KEGA No. 006UMB-4/2017 Creation of doctoral school model with emphasis on innovative supporting methods of scientific-research competences. 


\section{References}

Anossova, O. G. \& Dmitrichenkowa, S. V. (2018). Sociocultural, intercultural and translation competence for engineering students. JoLaCe, 6(2), 71-81.

Arphattananon, T. (2018). Multicultural education in Thailand. Intercultural Education, 29(2), 149-162.

Banks, J. A. (2010). Multicultural education: Characteristics and goals. In J. A. Banks \& C. A. Banks (Eds.), Multicultural Education: Issues and perspectives (7th ed., 130). New York, NY: John Wiley.

Barrett, M., Byram, M., Lázár, I., Mompoint, Gaillard, P., \& Philippou, S. (2014). Developing intercultural competence through education. Strasbourg: Council of Europe Publishing.

Byram, M., Barrett, M., Ipgrave, J., Jackson, R., \& Méndez García, M.C. (2009). Autobiography of intercultural encounters: Context, concepts and theories. Strasbourg, France: Council of Europe Publishing. Retrieved from https://www.coe.int/t/dg4/autobiography/source/aie_en/aie_context_conce pts_and_theories_en.pdf.

Caruana, V. (2011). Internationalisation and diversity: Exploding myths and making connections. Discovering Pathways for Inclusion: a focus on learning for diversity. Retrieved from http://www.heacademy.ac.uk/resources/detail/internationalisation/Viv_Car uana_Leeds_Met.

Chen, G. M., \& Starosta, W. J. (1996). Intercultural communication competence: A synthesis. Communication Yearbook, 19, 353-384.

Chigisheva, O., Soltovets, E., \& Bondarenko, A. (2017). Functional foreign language literacy for global research career development: analysis of standardized openended interview responses. XLinguae, 10, 138-153.

Cole, D., \& Spišiaková, M. (2017). Writing to be read. Philologica LXXXVI Lingua Academica, 5, 43-52. Bratislava, SK: Comenius University.

Council of Europe. (2018). CEFR - Common European Framework of Reference for Languages: Learning, Teaching, Assessment. Companion volume with new descriptors. Retrieved from https://rm.coe.int/cefr-companion-volume-withnew-descriptors-2018/1680787989.

Crose, B. (2011). Internationalization of the higher education classroom: Strategies to facilitate intercultural learning and academic success. International Journal of Teaching and Learning in Higher Education, 23, 388395.

Dearden, J. (2014). English as a medium of instruction - a growing global phenomenon. The British Council. Retrieved from

https://www.britishcouncil.org/sites/default/files/e484_emi_-

_cover_option_3_final_web.pdf. 
Deardorff, D. K. (2006). The identification and assessment of intercultural competence as a student outcome of internationalization. Journal of Studies in International Education, 10, 241-266.

European Centre for Clinical Research Training. (2018). Intercultural communication skills. Retrieved from http://www.eccrt.com/courses/intercultural-communication-skills.

European Commission. (2016). Communication from the Commission to the European Parliament, the Council, the European economic and social committee and the Committee of the regions: A New Skills Agenda for Europe. Brussels. Retrieved from http://eur-lex.europa.eu/legalcontent/EN/TXT/?uri=CELEX:52016DC0381.

European Commission. (2018). ESCO Strategic framework: European Skills, Competences, Qualifications and Occupations. ESCO Board. Retrieved June 4, 2018 from https://ec.europa.eu/esco/portal/home.

European Commission. (2018). Europe 2020: A European strategy for smart, sustainable and inclusive growth. European Commission. Retrieved from http://ec.europa.eu/eu2020/pdf/COMPLET\%20EN\%20BARROSO\%20\%20\% 20007\%20-\%20Europe\%202020\%20-\%20EN\%20version.pdf.

Genç, G. (2018). Are Turkish EFL pre-service teachers ready to manage intercultural challenges? Intercultural Education, 29(2), 185-202.

Gopal, A. (2011). Internationalization of higher education: Preparing faculty to teach cross-culturally. International Journal of Teaching and Learning in Higher Education, 23, 373-381.

Janík, Z. (2017). Negotiation of identities in intercultural communication. JoLaCe, 5(1), 160-181.

Javorčíková, J. (2009). Lessening of Englishness: Traditional Values at the Beginning of a New Millenium. In R. Trušník \& K. Nemčoková (Eds.), Theories in practice: proceedings of the First International Conference on English and American Studies (195-204). Zlín, CZ : Univerzita Tomáše Bati.

Kosová, B. (2012). Filozofické a globálne súvislosti edukácie. [Philosophical and global context of education]. Banská Bystrica, SK: Faculty of Education, MBU.

Lázár, I. (2011). Teachers' beliefs about integrating the development of intercultural communicative competence. Case studies of Hungarian preservice English teachers. Forum Sprache, 5, 113 -127.

Lujić, R. (2018). Classroom Participation as a Performative Act of Language Learners' Identity Construction. JoLaCe, 6(3), 72-84.

Michelson, K. (2017). Teaching culture as a relational process through a miltiliteracies-based global simulation. Language, Culture and Curriculum, 31(1), 1-20.

Morgado, M. (2017). Intercultural communicative competence. In E. Císlerová \& M. Štefl. (Eds.), Intercultural communicative competence: A competitive advantage 
for global employability (p. 10-12). Prague, CZ: Czech Technical University in Prague.

Stone, N. (2006). Conceptualising intercultural effectiveness for university teaching. Journal of Studies in International Education, 10, 334-356.

Sun, Y. (2014). What is intercultural communicative competence? 15.12.2014. Retrieved from blog.tesol.org/what-is-intercultural-communicativecompetence/.

Svitačová, E., Mravcová, A., \& Moravčíková, D. (2015). Globálne rozvojové vzdelávanie na Fakulte ekonomiky a manažmentu SPU v Nitre v Nitre [Global developmental education at the Faculty of Economics and Management, SPU in Nitra]. Pedagogika, 6, 24-43.

Vančíková, K. (Ed.) (2013). Multikultúrna výchova - jej miesto v príprave učitel’ov. [Multicultural education - its role in teacher preparation]. Banská Bystrica: Faculty of Education, MBU.

Zelenková, A. (2010). Interkultúrne vzdelávanie v cudzích jazykoch na vysokej škole: Metódy a ich reflexia. [Intercultural education in foreign languages at university: Methods and their reflection]. Banská Bystrica, SK: Faculty of Economics, MBU. Zerzová, J. (2018). Opportunities to Develop Intercultural Communicative Competence in Czech lower-secondary schools: Findings of the IRSE Video Study of German. JoLaCe, 6(3), 101-121.

\section{Contact}

Doc. PhDr. Anna Zelenková, PhD.

Matej Bel University

Faculty of Economics

Tajovského 10

97590 Banská Bystrica

Slovakia

anna.zelenkova@umb.sk

Prof. PaedDr. Dana Hanesová, PhD.

Matej Bel University

Faculty of Education

Ružová 13

97411 Banská Bystrica

Slovakia

dana.hanesova@umb.sk 